\section{The Challenges of Growing Strawberries in the Greenhouse}

\author{
Ellen T. Paparozzi ${ }^{1}$
}

\begin{abstract}
ADDITIONAL INDEX WORDS. capillary mats, costs, high tunnels
Summary. As a floriculturist, when I first decided to grow strawberries (Fragaria $\times$ ananassa) in the greenhouse, I thought it would be a snap. After all, I could practice what I preach to my classes in that I would use all the sustainable growing tricks from floriculture, create a production time line and it would be ready, set grow. However, moving a field-grown summer crop into a greenhouse as a winter crop was not the same as moving a winter greenhouse-grown crop outside for the summer. Not only were the plants typically grown in lush field soil, but also the fertilizer recommendations were not directly translatable (i.e., parts per million nitrogen). The pesticides used were not licensed for greenhouses and of course, there were no clues as to schedules of what to do when. Finally, there were the mystery problems that occurred. With high gas prices and the interest in local food production, it seems probable that over the next 5 to 10 years, more and more fruit, vegetables and even nut plants will be moved into greenhouse and high tunnel production. The purpose of this article is to identify the kinds of information needed to make a "smooth" transition from field to greenhouse for alternative crops, like strawberries, grown during nontraditional seasons.
\end{abstract}

$\mathrm{F}$ loriculturists, by virtue of their training and education across practical as well as scientific disciplines, bring specialized and unique skills for successful adaptation of field crops to greenhouse production. With the interest in food crop season extension through high tunnels, increased shipping costs and consumer support for local and sustainable food production, the logical next step is the production of more food crops in greenhouses. A greenhouse or heated high tunnel offers growers the ability to manipulate water, light, and heat as well as minimize/prevent diseases and insects. However, moving vegetable and fruit crops from field to greenhouse production, especially offseason, brings a variety of challenges often not anticipated. In this article, I will identify challenges both expected

Department of Agronomy and Horticulture, University of Nebraska-Lincoln, Lincoln, NE 68583-0724

This research was funded in part by grants from the Nebraska Department of Agriculture-Horticulture Specialty Block Grant Program and the USDA/ CSREES Multistate project NE-1035 “Commercial greenhouse production: Component and System Development."

This article was part of the National Floriculture Forum "Creative Thinking, Creative Funding: Research, Extension, and Teaching Programs and Consortiums" held 22-24 Mar. 2013 in Portsmouth, NH; and hosted by the University of Maine, University of New Hampshire, Purdue University, and Cornell University.

${ }^{1}$ Corresponding author. E-mail: etpl@unl.edu. and unexpected for strawberry growing in the greenhouse during the winter.

\section{Methods}

The hallmark for starting research for any new crop is the literature review. Books in the general area, fruit science, as well as on the specific crop are a great starting point (Darrow, 1966; Hancock, 1999; Pritts and Handley, 1998; Takeda, 1999). Journal article searches are of course helpful, but finding proceedings and extension publications (which is more difficult) often give the more practical insight that is needed (Cantliffe et al., 2007; Rowley et al., 2010). Using our strawberry research as an example, when I started to construct the production time line I realized that first we needed to find sources from which to purchase them. It was daunting to find that most plants are sold out by April and the latest delivery time was the beginning of September. When contacting growers, they were unsure that my plans to grow strawberries during the winter made any sense. After all, strawberries are planted in the field as small plants and they stay there until harvest and then stored as dormant crowns. Sometimes runners/stolons are removed and used for propagation. Some growers (like U-pick operations) overwinter them for the next year, but for most large commercial operations, strawberries are treated like an annual crop. Finding crowns in the fall meant having freshly dug crowns in October (which are not usually for sale), finding a grower that ships small potted plants (expensive, particularly if organically grown) or one who will ship dormant crowns at the end of the season. Fortunately, members of the team had connections with the fruit industry, both commercial and university, so we were able to obtain plants and accomplish a shortterm cultivar trial our first year.

When this idea was first proposed, there were many criticisms of this research. They included the "fact" that Nebraska did not have enough winter light for strawberry flower and fruit production and that both water and heat would be too costly to produce a profit particularly if the initial cost of constructing and setting up the greenhouse was added.

\section{Results and discussion}

Our team took these challenges and addressed them by proposing a double polyethylene structure (heated high tunnel) with easily constructed, removable, low-cost benches, and an automated capillary mat fertigation system (Phytotronics, Earth City, MO) to minimize water usage and labor (Lambe et al., 2012). We decided to reduce the evaporation from the mat system by creating a plastic sandwich-6-mil black polyethylene (Hummert International, Earth City, $\mathrm{MO}$ ) on the bottom, then the fiber mat with drip tape, and a top layer of plastic. To increase light, in a costeffective manner, we tested different colors of plastic for use as the top layer and determined that 6-mil white

\begin{tabular}{llll}
\hline $\begin{array}{l}\text { Units } \\
\text { To convert U.S. to SI, } \\
\text { multiply by }\end{array}$ & U.S. unit & SI unit & $\begin{array}{l}\text { To convert SI to U.S., } \\
\text { multiply by }\end{array}$ \\
\hline 0.3048 & $\mathrm{ft}$ & $\mathrm{m}$ & 3.2808 \\
0.0254 & $\mathrm{mil}$ & $\mathrm{mm}$ & 39.3701 \\
28.3495 & $\mathrm{oz}$ & $\mathrm{g}$ & 0.0353 \\
1 & $\mathrm{ppm}$ & $\mathrm{mg} \cdot \mathrm{kg}^{-1}$ & 1 \\
1 & $\mathrm{ppm}$ & $\mathrm{mg} \cdot \mathrm{L}^{-1}$ & 1 \\
$\left({ }^{\circ} \mathrm{F}-32\right) \div 1.8$ & ${ }^{\circ} \mathrm{F}$ & ${ }^{\circ} \mathrm{C}$ & $\left({ }^{\circ} \mathrm{C} \times 1.8\right)+32$
\end{tabular}


polyethylene (Hummert International) would increase light in the visible wavelengths by $75 \%$ to $80 \%$ (Meyer et al., 2012). Little did we know that the low transmissivity of the white plastic would still allow algae to grow! We solved that problem the next year by using white top black bottom polyethylene sometimes called panda plastic (Horticulture Source, Vancouver, WA). This polyethylene was more expensive, but we no longer had algae problems. However, if the polyethylene was allowed to overhang the benches to mimic a heat skirt, the humidity increased dramatically and caused problems. This was rectified by trimming the white black poly after placement so that it hung over each side about 6 inches. Still there was powdery mildew (Podosphaera sp.) on the medium surface in some pots, but the recommended solution of scraping it off worked well.

To address the start-up cost concerns, our benches were constructed of a wood frame with bench fabric (Southeastern Wood Products Co., Griffin, GA) on top and built as one unit. The bench legs consisted of cinder blocks, thus allowing easy construction and removal, if necessary. Posts for the hoop structures would be sunk into concrete "shoes" and the floor would be compacted soil. Weed barrier (Hummert International) for under benches and gravel is optional. We estimated the total cost of materials to be about $\$ 20,000$ plus labor for a $24 \times 75$-ft greenhouse (Lambe et al., 2012).

To address the consumption of water and energy, the heat was provided by two gas furnaces (one would have been sufficient) with the venting organized such that the polyethylene tubes that delivered the hot air were situated under the benches. Temperatures were set to $62 / 75^{\circ} \mathrm{F}$ night/ day and we used a computer to keep track of the heating and cooling events. We also installed a gas meter to keep track of the usage during our growing season.

For water, using a common lawn irrigation clock (Rain Bird Corp., Azusa, CA), we set the mats to receive water once or twice per day for 1-3 min per time, depending on the season. We installed a water meter that measured our water consumption. The challenges here were getting the meters installed in a timely manner as we could not do these ourselves. Allow double the time the installer indicates! As far as using the capillary mat system, if the mat is allowed to drip, the humidity increases, transpiration decreases, and powdery mildew will start to appear in pots and on leaves. So, while daily hand watering was not needed, we still scouted the plants. Also, in our quest for sustainability, the first year, we potted up one pot in each replication with wood fiber pots. Unfortunately, the mat system kept those pots too moist. Powdery mildew appeared on the sides of the containers so we had to replace them with plastic.

Cultivar trials and tribulations also occurred. Because this was both a new system and out-of-season, we were advised by colleagues to conduct a trial with both short-day (Junebearing) cultivars such as AC Wendy, Cavendish, Chandler, Clancy, Darselect, Honeoye, Sweet Charlie, and Strawberry Festival as well as dayneutral (ever-bearing) cultivars Albion, Evie-2, Portola, Seascape, and Tribute. The challenge here was which cultivar(s) to select. Fortunately, the strawberry experts and breeders at other universities and in industry were willing to help us to create a list. The ones that were available in September (listed above) helped to further reduce the number to 13 total. Cultural recommendations were set for field production so challenges here included mix composition, fertilizer requirements, pesticides vs. biological controls vs. beneficial insects, and providing enough air circulation for tight habit cultivars to insure adequate plant transpiration. The fertilizer challenge included figuring out adequate concentrations of nitrogen $(\mathrm{N})$, potassium, calcium, and boron to get well-formed fruit. We decided to use 100 ppm $\mathrm{N}$ from a "complete" water-soluble fertilizer. When calcium deficiency occurred, we used calcium nitrate at $100 \mathrm{ppm} \mathrm{N}$ to correct deficiency.

For pests, we anticipated that bringing the plants inside would expose them to a higher insect pressure, but what we did not anticipate was the bee-pesticide interaction. Most of the recommended fungicides and other pesticides were either not labeled for the greenhouse or could not be used with our pollinating bumble bees (Bombus impatiens). Just using the bees was a bit of a challenge as they require care such as fresh clear water complete with places to land to drink. This threw us into a crash course on using biologicals as the timing of their release is critical for successful control. We minimized our pest issue by weeding 2-3 ft around all sides of the greenhouse and then 1 week before the start of the experiment, completely sterilizing (hypochloric acid $40 \%$ concentration) the greenhouse sides and floors as well as under and on all benches though not on the capillary mats.

Despite problems, during our preliminary experiment, 'Albion' and 'Evie-2' plants each produced over $2388 \mathrm{~g}$ of berries from 24 plants per cultivar and all other cultivars except Chandler and Sweet Charlie produced over $1000 \mathrm{~g}$ of berries (Paparozzi et al., 2011). However, just because an experiment worked well 1 year does not mean it will again. Many of the grants available are 1 year in length and so we are led to think that we can get it done. The problem with this is that the more you work with a system the more able you are to detect the little things that can go wrong or need to be adjusted. For example, our fertilizer proportioner went through two hot summers just fine. Then during Summer 2012, when we were experiencing extreme heat, despite cooling pads, the seal broke. We now know to cover the proportioner with white plastic and reprogram the vents to open sooner each morning. The second year we were growing the strawberries, they displayed fruit phylloidy (Jomantiene et al., 2000). These little leaves, where the achenes should be, make them unmarketable. As a result, we had to eliminate a cultivar we thought would be an excellent choice.

\section{Conclusions}

It is attention to the little things and being able to anticipate that will make the transition run smoothly and be successful. Here are some steps to help. Start by choosing a highly marketable plant, preferably one with many alternative markets, not just fresh to help identify stakeholders. Dig out practical as well as scientific information to have on hand to complete a first draft of the step-by-step transition from field to greenhouse. Then create production time lines with all cultural steps and materials needed for how the crop is typically grown in the field. Create one for the 
greenhouse/high tunnel and identify gaps. Use this knowledge to contact other university specialists and engage growers. Readjust the production time line, identify the cultural procedures that need to be tested and then consult with your statistician to create the best possible design(s) for your experiments.

\section{Literature cited}

Cantliffe, D.J., J.Z. Castellanos, and A.V. Paranjpe. 2007. Yield and quality of greenhouse-grown strawberries as affected by nitrogen level in coco coir and pine bark media. Proc. Fla. State Hort. Soc. 120:157-161.
Darrow, G.M. 1966. The strawberry: History, breeding and physiology. Holt, Rinehart and Winston, New York, NY.

Hancock, J.F. 1999. Strawberries. CABI Publ., New York, NY.

Jomantiene, R., J.L. Maas, E.L. Dally, and R.E. Davis. 2000. Strawberry fruit phyllody caused by phytoplasmas. HortScience 35:391, (Abstr.).

Lambe, D., S. Adams, and E.T. Paparozzi. 2012. Estimating construction costs for a low-cost Quonset-style greenhouse. Univ. Nebraska Coop. Ext. EC 104.

Meyer, G.E., E.T. Paparozzi, E.A. WalterShea, E.E. Blankenship, and S.A. Adams 2012. An Investigation of reflective mulches for use over capillary mat systems for winter-time greenhouse strawberry production. Appl. Eng. Agr. 28:271279.

Paparozzi, E.T., G.E. Meyer, M.E. Conley, S.A. Adams, E.E. Blankenship, P.E. Read, and V.L. Schlegel. 2011. Cultivar choice affects quality and production of wintergrown strawberries. HortScience 46:S112S113 (abstr.).

Pritts, M. and D. Handley. 1998. Strawberry production guide. Northeast Reg. Agr. Eng. Serv., Ithaca, NY.

Rowley, D., B.L. Black, and D. Drost. 2010. Strawberry Plug Plant Production. 13 Aug. 2013. <http://extension.usu. edu/files / publications / publication/ Horticulture_Fruit_2010-01pr.pdf $>$.

Takeda, F. 1999. Out of season greenhouse strawberry production in a soilless substitute. Adv. Strawberry Res. 18:4-15. 